\title{
Notes on rhopalosomatid wasps of Dominican and Mexican amber (Hymenoptera: Rhopalosomatidae) with a description of the first fossil species of Rhopalosoma Cresson, 1865
}

\author{
Volker Lohrmann ${ }^{1,2}$, Michael Ohl ${ }^{2}$, Peter Michalik ${ }^{3}$, James P. Pitts ${ }^{4}$, Laurent Jeanneau ${ }^{5}$, and Vincent Perrichot ${ }^{5}$ \\ ${ }^{1}$ Übersee-Museum Bremen, Bahnhofsplatz 13, 28195 Bremen, Germany \\ ${ }^{2}$ Museum für Naturkunde, Leibniz-Institut für Evolutions- und Biodiversitätsforschung, Invalidenstraße 43, \\ 10115 Berlin, Germany \\ ${ }^{3}$ Zoologisches Institut und Museum, University of Greifswald, Loitzer Str. 26, 17489 Greifswald, Germany \\ ${ }^{4}$ Department of Biology, Utah State University, 5305 Old Main Hill, Logan, UT 84322-5305, USA \\ ${ }^{5}$ Géosciences Rennes, Univ. Rennes, CNRS, UMR 6118, 35000 Rennes, France
}

Correspondence: Volker Lohrmann (v.lohrmann@uebersee-museum.de)

Received: 2 November 2018 - Revised: 11 January 2019 - Accepted: 18 January 2019 - Published: 15 May 2019

\begin{abstract}
Rhopalosomatidae are a family of aculeate wasps that are ectoparasitoids of crickets as larvae and are predominantly distributed pantropically. The published fossil record of the family is scarce. Here, we report three new fossil rhopalosomatid wasp specimens from Dominican and Mexican amber. Rhopalosoma hispaniola Lohrmann sp. nov. is described and documented from Dominican amber by two separate inclusions - one of each sex. An additional fossil female Rhopalosoma is described and documented from Mexican amber but is not named due to the insufficient preservation of the fossil. The new fossils, which are morphologically intermediate between Townes' isopus and poeyi species groups, do not only represent the first fossil records of an extant genus of this peculiar family but also the first records of the family in Dominican and Mexican amber.
\end{abstract}

\section{Introduction}

The Recent New World fauna of Rhopalosomatidae is currently comprised of 35 formally described species assigned to three genera: Liosphex Townes, 1977, with 13 species, Olixon Cameron, 1887, with 5 species, and Rhopalosoma Cresson, 1865, with 17 species (Townes, 1977; Lohrmann and Ohl, 2010; Lohrmann et al., 2012). Their distribution ranges from southeastern Canada and the northeastern USA to northern Argentina and southern Brazil, with the vast ma- jority occurring in the tropic zone. As far as it is known, female rhopalosomatids hunt for crickets (Orthoptera) that ultimately serve as hosts for their ectoparasitoid larvae (Perkins, 1908; Hood, 1913; Gurney, 1953; Lohrmann et al., 2014; Blaschke et al., unpublished results; see also Fig. 1a-b).

The recent discovery of an ectoparasitoid rhopalosomatid wasp larva attached to its cricket host in mid-Cretaceous Burmese amber revealed a remarkable constancy of the biology of Rhopalosomatidae over the last 100 million years (Lohrmann and Engel, 2017). In some way, this extraordinary fossil hides the fact that we still know little about the origin and evolution of this peculiar family of aculeate wasps. Two of the four fossil taxa previously assigned to the family, Mesorhopalosoma Darling (in Darling and Sharkey, 1990) and Paleorhopalosoma Nel et al., 2010, have been transferred to the sphecoid wasps (Osten, 2007; Archibald et al., 2018). Additionally, Propalosoma Dlussky and Rasnitsyn, 1999, has been transferred to the myrmeciine ants (Archibald et al., 2018). This leaves Eorhopalosoma Engel, 2008, which is another Cretaceous Burmese amber fossil, as the sole fossil species in the family so far.

No Rhopalosomatidae have been recorded from Dominican and/or Mexican amber, even though many of the extant aculeate families currently distributed in the neotropics are already reported from either of these contemporary outcrops. For Dominican amber, these include Andrenidae, Apidae, Bethylidae, Chrysididae, Crabronidae, Colletidae, Dryinidae, Formicidae, Halictidae, Megachilidae, Mutilli- 

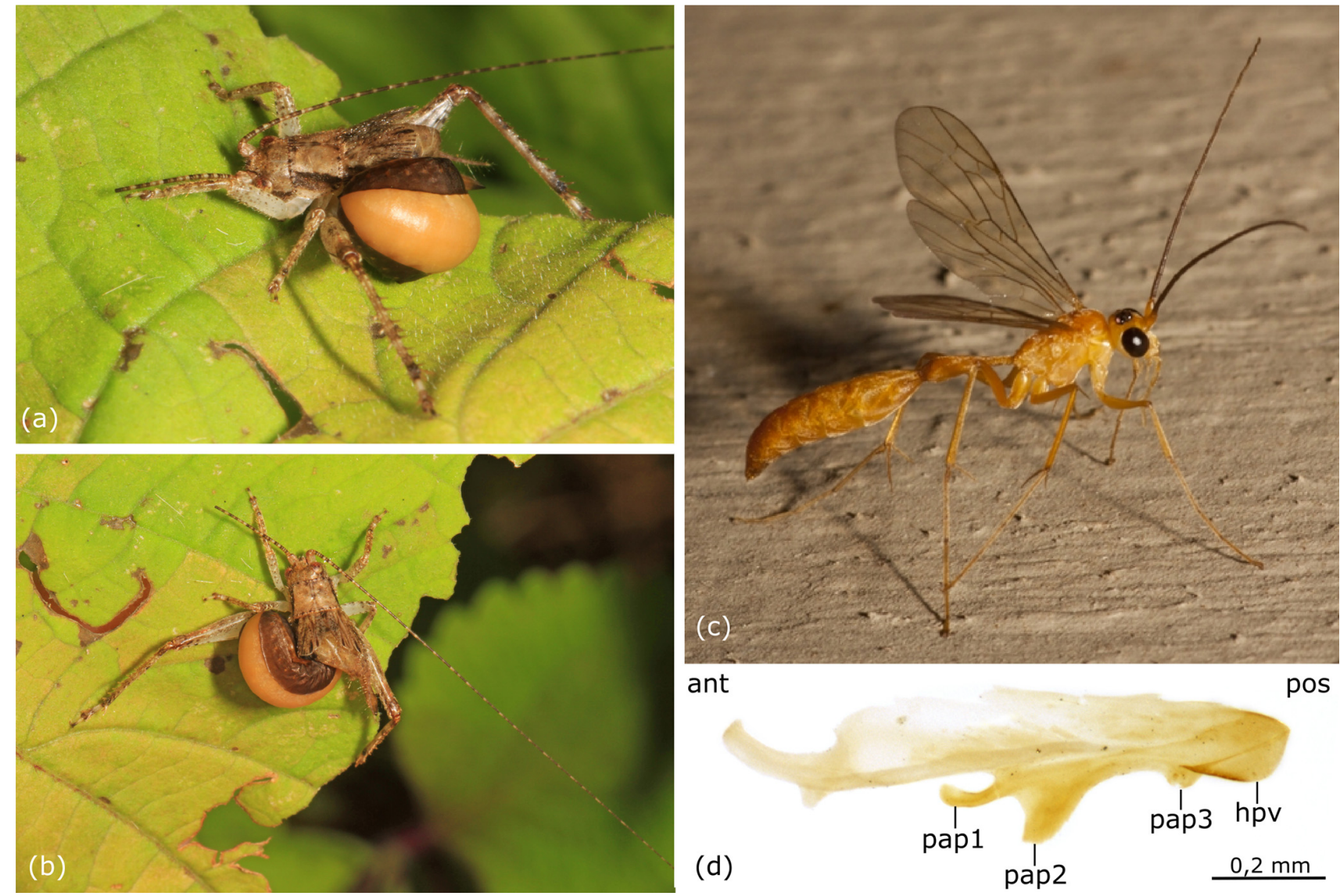

ant

pos

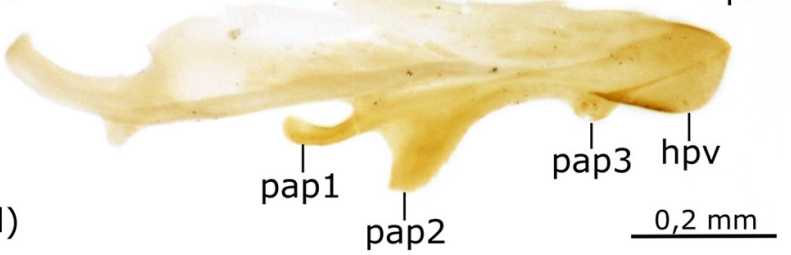

Figure 1. Rhopalosomatidae spp. (a-b) Recent rhopalosomatid larva (last instar, shortly before leaving the host, putatively Rhopalosoma nearcticum Brues) parasitizing a hapithine cricket (Grylloidea). Photographed at Jones Nature Preserve, Rappahannock County, Virginia, USA, on 15 September 2017. Photos: Judy Gallagher, CC-BY-2.0, originally posted to Flickr. (c-d) Rhopalosoma nearcticum Brues, male. (c) Photographed in Mobile (Dog River), Mobile County, Alabama, USA, on 4 July 2011. Photo: Robert Lord Zimlich, originally posted to BugGuide. (d) Penis valve in lateral view. Abbreviations: ant - anterior, hpv - head of penis valve, pap1 - first preapical process, pap2 second preapical process, pap3 - third preapical process, and pos - posterior.

dae, Pompilidae, Sclerogibbidae, Scolebythidae, and Vespidae (Penney, 2010; Rodriguez et al., 2016). For Mexican amber, these include Apidae, Bethylidae, Dryinidae, and Formicidae (Solórzano Kraemer, 2010).

Due to their general appearance, members of the rhopalosomatid wasp genus Rhopalosoma (see Fig. 1c), as well as the Old World Paniscomima Townes, 1977, are often mistaken for nocturnal ichneumonids, e.g., Ophion spp. or Netelia spp. (McGown, 1998), and one is strongly encouraged to go through collections of unidentified subtropical or tropical nocturnal ichneumonids when searching for material of the genus. This is also true for the fossil record. During our surveys of fossil inclusions, three adult rhopalosomatid wasps have been discovered in Dominican and Mexican amber, and one of the fossils described herein was indeed initially identified and advertised as a "Large Ichneumonid Wasp".

All three of the new fossils belong to the Recent genus Rhopalosoma. The aim of the present study is to describe and illustrate these fossils, which are not only the first fossil records of the genus but are also the first of the family from Dominican and Mexican amber and from the Miocene as a whole.

\section{Materials and methods}

\subsection{Thermochemolysis-gas chromatography-mass spectrometry}

Of the three new rhopalosomatid fossils reported herein, each is preserved in a separate amber piece. Two of these fossils originate from the La Bucara mine in the Dominican Republic, and one comes from a mine in Mexico (Chiapas). Because the Mexican amber piece was obtained from an online auction, without an indication of the exact provenance in Chiapas, we performed a chemical analysis to ascertain its amber vs. copal nature and its affinities with genuine Chiapas amber. Thermochemolysis-gas chromatography-mass 
spectrometry (THM-GC-MS) was performed on both the Mexican amber sample and a piece of yellowish Baltic amber as a reference chromatogram. Small portions of amber were crushed manually in an agate mortar. The powder $(\sim 0.1 \mathrm{mg}$ ) was heated with TMAH (tetramethylammonium hydroxide) at $400^{\circ} \mathrm{C}$. THM was carried out using a Frontier Lab PY-2020iD pyrolyzer coupled with a Shimadzu GCMSQP2010 Plus system operating with a split ratio of 100. Separation was achieved using a capillary column SLB-5ms $(60 \mathrm{~m} \times 0.25 \mathrm{~mm}$ inner diameter - ID, $0.25 \mu \mathrm{m}$ film thickness) with the carrier gas He with a flow of $1.1 \mathrm{~mL} \mathrm{~min}^{-1}$. The operating conditions were as follows. The initial temperature was held at $50^{\circ} \mathrm{C}$ for $2 \mathrm{~min}$ and was increased to $310^{\circ} \mathrm{C}$ at a rate of $4^{\circ} \mathrm{C} \mathrm{min}^{-1}$ for $34 \mathrm{~min}$. Individual compounds were identified based on comparison of (i) MS data with the NIST 2014 library and literature (Anderson, 1994, 1995) and (ii) retention time with the Baltic amber. The molecules were referenced according to Anderson (1995).

The relative distribution of identified compounds was determined by measuring the area of a specific fragment, denoted as $m / z$ integration in Appendix A. The peak area of the selected $m / z$ for each compound was integrated and corrected by a mass spectra factor (Appendix A) calculated as the reciprocal of the proportion of the fragment used for the integration and the entire fragmentogram. The molecular ratios were calculated using those corrected areas that allow an approximation of areas on the total ion chromatogram, while preventing from the simultaneous analysis of co-eluting compounds.

\subsection{Age of the amber}

There has been a wide range of proposed ages for Dominican amber, from $45 \pm 9$ to $15 \mathrm{Ma}$ (Lambert et al., 1985; Schlee, 1990; Landis and Snee, 1991; Grimaldi, 1995). However, most recent studies reviewing its geological dating indicate a late Early to early Middle Miocene age (about 15-20 Ma; Iturralde-Vinent and MacPhee, 1996; Iturralde-Vinent, 2001; and Penney, 2010 for a review). Mexican amber is of similar age (15-20 Ma; Solórzano Kraemer, 2007, 2010, but see Serrano-Sánchez et al., 2015, for a slightly older Miocene dating), which is supported by the similarities of the organismal inclusions of these two amber deposits. Indeed, many insect and arachnid genera are found in both Dominican and Mexican amber (Solórzano Kraemer, 2010). Yet, the authors are not aware of a single species in common described or recorded in both ambers.

\subsection{Preparation and study of fossils}

All three amber pieces were manually polished using a Buehler MetaServ 3000 polisher and Buehler CarbiMet silicon carbide papers to obtain flat surfaces for optimal observation and imaging of the insect inclusions.
The inclusions were studied with a Leica MZ12 and a Zeiss SteREO Discovery.V20 stereomicroscope. Measurements were taken with an ocular micrometer. Extended-focus images were taken with a Leica DFC 490 digital camera with a Leica Z16 Apo A system and a Canon 5D Mark II digital camera attached to the Leica MZ APO stereomicroscope or with the BK PLUS Lab system (Dun Inc.) with a Canon MPE $65 \mathrm{~mm}$ lens mounted on a Canon 6D camera. Pictures were aligned and stacked using the software package AutoMontage Essentials by Syncroscopy (Version 5.03.0061 ES), Helicon Focus software (Helicon Soft Ltd., version 6.7.2), or Zerene Stacker under the PMax value.

The general morphological terminology is adopted from Huber and Sharkey (1993), with additions from Mason $(1986,1990)$, and the following morphological abbreviations and modifications are used in the text. $\mathrm{Cu}^{2}$ is the section of fore wing cubitus separating the $2 \mathrm{Cu}$ and $2 \mathrm{M}$ (not closed) cells (Fig. 4f). IOD is the interocellar distance, or the shortest distance between the lateral ocelli. LOD is the maximum diameter of a lateral ocellus. MOD is the maximum diameter of the median ocellus. $\mathrm{M}^{1}$ is the section of fore wing media separating the $\mathrm{R}$ and $1 \mathrm{M}$ cells (Fig. $4 \mathrm{f}$ ). $\mathrm{M}^{2}$ is the section of fore wing media separating the $1 \mathrm{M}$ and 1 Rs cells (Fig. 4e). OOD is the ocellocular distance, or the shortest distance between the lateral ocellus and eye. Rs ${ }^{1}$ is the section of fore wing radial sector separating the 1R1 and 1Rs cells (Fig. 4e). $\mathrm{Rs}^{*}$ is the section of hind wing radial sector separating the $\mathrm{R}$ and R1 cells (Fig. 5e). TL is the temple length, or the shortest distance between the posterior eye margin and occipital carina.

All three specimens are deposited in the amber collection of the Museum für Naturkunde in Berlin, Germany (inventory numbers: MB.I 5915, MB.I 6046, and MB.I 6549).

\subsection{Reference material studied}

During the course of this research, the holotypes of Rhopalosoma alvarengai Townes, 1977, R. angulare Townes, 1977, $R$. breelandi Townes, 1977, R. impar Townes, 1977, R. isopus Townes, 1977, R. minus Townes, 1977, R. obliquum Townes, 1977 , and $R$. scaposum Townes, 1977, all deposited in the Entomology Collection of Utah State University (EMUS), previously known as the American Entomological Institute (AEI), were studied. Additionally, non-type material of the EMUS, including $R$. bahianum Schulz, 1906, R. breelandi, R. guianense Schulz, 1906, R. haitiense Townes, 1977, R. impar, $R$. isopus, $R$. minus, $R$. nearcticum Brues, 1943, $R$. poeyi Cresson, 1865, and $R$. simile Brues, 1943, was also studied.

\subsection{Nomenclatural acts}

This published work and the nomenclatural acts it contains have been registered in ZooBank (http://www.zoobank.org/, last access: 1 October 2018), with the following LSID 
(reference): urn:lsid:zoobank.org:pub:1BA7DC1A-E890465C-BF6D-F0A95C131B48. The electronic edition of this work has been archived and is available from the following digital repositories: Deutsche Nationalbibliothek, US Library of Congress, Portico, and CLOCKSS.

\section{Results}

\subsection{Chemical analysis}

The THM-GC-MS analysis of the Mexican resin sample (Fig. 2; see also Appendix B) revealed characteristic bicyclic products derived from polylabdanoid structures including carboxylic acids (XIa-XIVa), analyzed as their methyl ester; alcohols (XIIIb-XIVb) partially methylated (XIIId-XIVd); and hydrocarbons (XIc, XIIIc and XIVc). Moreover the THM of this sample also produced 1-methylbicyclic hydrocarbons (A-K) that are believed to come from A-ring defunctionalization (Anderson, 1995).

The shift in the retention times of methylic ether XIIId and XIVd between the Baltic amber and the Mexican resin (Fig. 3) indicated an enantio configuration for the latter. Consequently, it falls into the class Ic as defined by Anderson et al. (1992). The distribution of bicyclic products derived from the polylabdanoid macromolecular structure of the Mexican sample was dominated by 1-dimethylbicyclic and 1methylbicyclic hydrocarbons (50\% and $28 \%$, respectively), while bicyclic acids and alcohols represented only $6 \%$ and $17 \%$ of those compounds, respectively (Table 1). This predominance of 1-dimethylbicyclic hydrocarbons was already observed in Sicilian amber (van der Werf et al., 2016).

The composition was compared to those of known class Ic ambers from the Eocene of Oise (France; Nohra et al., 2015) and the Miocene of the neotropics (the Dominican Republic and Mexico, from the collection of Vincent Perrichot, Univ. Rennes, unpublished results). The relative proportions of carboxylic acids, alcohols, and hydrocarbons among bicyclic products derived from polylabdanoid structures were similar in the Mexican sample and the two neotropical ambers, while the Oise amber was richer in carboxylic acids (Table 1). The proportion of 1-methylbicyclic hydrocarbons was proposed as a maturity proxy, since they are especially observed in samples of moderate thermal maturity (Anderson, 1995). The present Mexican sample (28\%) falls between Oise (19\%) and Dominican (22\%) ambers on one side and Mexican amber $(41 \%)$ on the other side, thus attesting to its amber rather than copal nature as well as its affinity with neotropical ambers.
With the exception of the earliest record of a class Ic amber from the Carboniferous (Bray and Anderson, 2009), all other known Ic ambers are Cenozoic and are derived from angiosperms of the legume family Fabaceae (Lambert et al., 2008; Nohra et al., 2015; van der Werf et al., 2016), particularly the genus Hymenaea Linnaeus that produced neotropical Miocene ambers from the Dominican Republic and Mexico (Anderson et al., 1992; Anderson, 1995).

\subsection{Systematic paleontology}

\section{Order Hymenoptera Linnaeus, 1758}

\section{Family Rhopalosomatidae Ashmead, 1896}

\section{Genus Rhopalosoma Cresson, 1865}

LSID (genus): urn:lsid:zoobank.org:act:F41B7AB70F40-40E6-AEC3-0B01AF718AF1

Rhopalosoma Cresson, 1865:58. Type species: Rhopalosoma poeyi Cresson, 1865, by monotypy.

Sibyllina Westwood, 1868:329. Type species: Sibyllina aenigmatica Westwood, 1868, by monotypy. Synonomy by Westwood, 1874: 130 .

\section{Diagnosis}

Among extant and fossil rhopalosomatids, species of Rhopalosoma are characterized by the following character combination. The wings are fully developed (brachypterous in Olixon); the occipital carina is present (absent in Liosphex); the apical section of the fore wing cubitus $\left(\mathrm{Cu}^{2}\right.$ in Fig. 4) is at least slightly sinuate (arched, but indented at the level of junction with $\mathrm{CuA}$ in Paniscomima, and almost straight in Eorhopalosoma); female pretarsal claws have a preapical tooth (as in Figs. 4b, 6c); female tarsomeres II-IV have apicolateral tarsal fenestrae (Fig. 6b); and the second preapical process of the male penis valve is narrow to broad, distad from the head of the penis valve, and is not overlapped at its apex by the third preapical process (Fig. 1d; broadly triangular, near head of penis valve, and overlapped in Paniscomima).

(Males and females of the family can be differentiated by the number of flagellomeres - males have 11, and females have 10 , by the number of visible metasomal tergites - males have 7 , and females have 6 , and by the form of tarsomeres II-IV - cylindrical for males and flattened for females. For a more detailed morphological description of the genus and all extant species, including a species-level identification key, the family revision of Townes (1977), should be consulted.) 


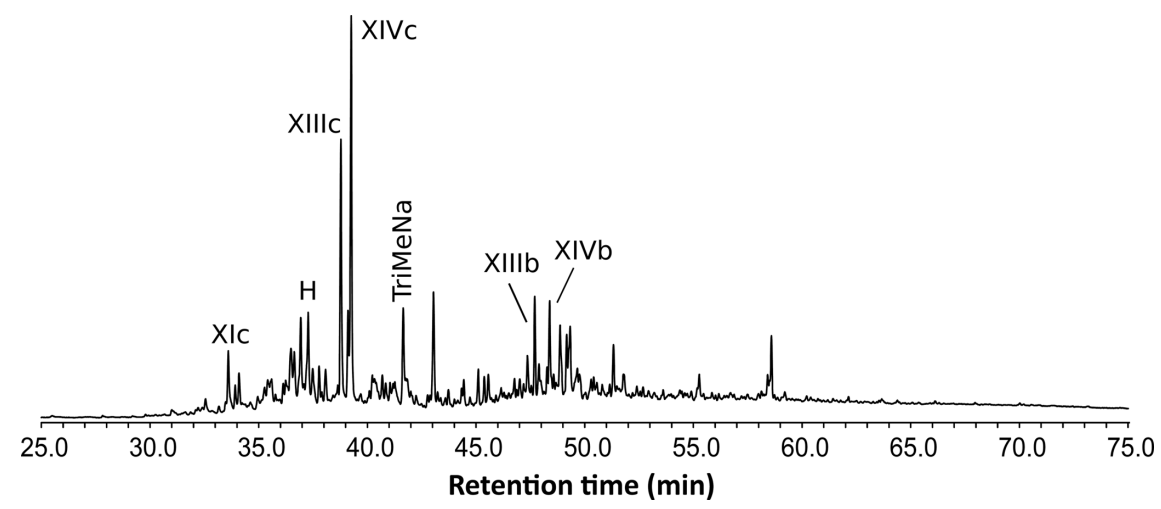

Figure 2. Chromatogram from the THM-GC-MS analysis of the Mexican sample. Numbered peaks refer to identified compounds in Appendix A. TriMeNa is trimethylnaphthalene.

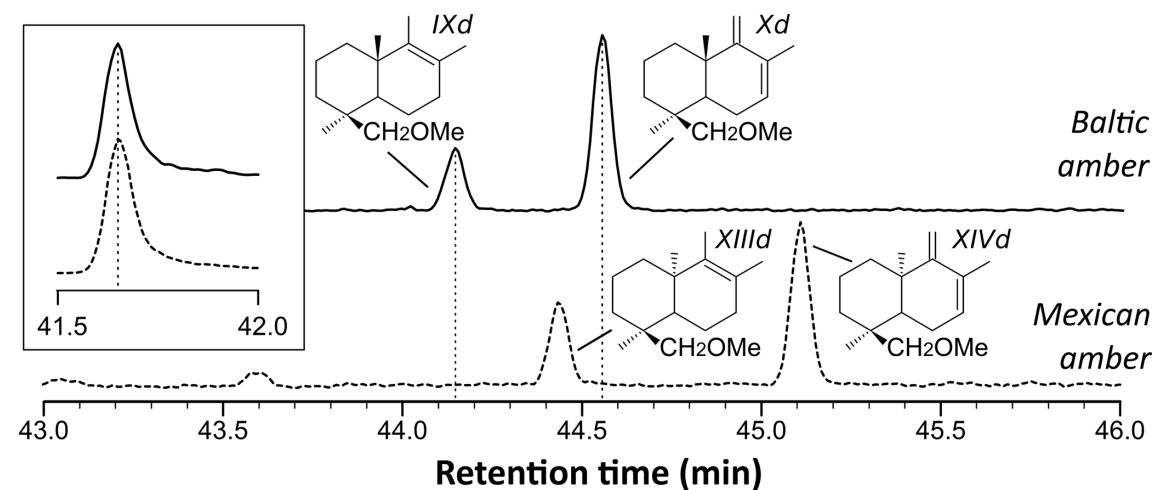

Figure 3. Reconstructed chromatogram $(m / z=234+236)$ of Baltic amber (solid line) and Mexican sample (dashed line). The shift in the retention times of compounds XIIId and XIVd (Mexican amber) compared to IXd and Xd (Baltic amber) is due to the difference of configuration between the enantio and regular forms, which classifies the Mexican sample as a class Ic resinite. The box depicts the similar retention time for trimethylnaphthalene $(m / z=155)$.

\section{Distribution}

Distribution is predominantly in the tropics and subtropics of the Americas (eastern United States to southern Brazil and northern Argentina), including some of the Caribbean countries (Bahamas, Cayman Island, Cuba, and Haiti; Townes, 1977).

\section{Biology}

As it concerns the extant fauna, Rhopalosoma nearcticum Brues, 1943, has been associated with species of trigonidiine and hapithine genera (Insecta: Orthoptera), i.e., Anaxipha Saussure, 1874, Hapithus Uhler, 1864, and Orocharis Uhler, 1864 (Hood, 1913 - misidentified as R. poeyi Cresson, 1865; Gurney, 1953; Townes, 1977; Blaschke et al., unpublished results; see also Fig. 1a-b). For the remaining 16 extant species in the genus, however, no data have been published to date on their host-parasite relationships.

\section{Rhopalosoma hispaniola Lohrmann sp. nov.}

LSID (species): urn:lsid:zoobank.org:act:6BEECB2C0403-4F5C-93DF-04590CF406DA

LSID (author): urn:lsid:zoobank.org:author:05A758C9462A-422C-B8D6-DD9530E2BD05

(Figs. 4, 5)

\section{Diagnosis}

Within Rhopalosoma, females of $R$. hispaniola are unique in showing the following character combination: hind wing $\mathrm{Rs}^{*}$ is straight and recurrent, and the apical 0.65 of fifth tarsomeres is tapered. Males of $R$. hispaniola resemble $R$. minus Townes, 1977, in having a straight, recurrent hind wing Rs* but can be differentiated by the position of the fore wing cu-a, which is distad of $\mathrm{M}^{1}$ by about $1.0 \times$ its length (about $2.0 \times$ in $R$. minus). 
Table 1. Relative proportions of characteristic bicyclic products derived from polylabdanoid macromolecular structures of the present Mexican sample compared with three classes of three class-Ic ambers. Amber from Dominican Republic and from Mexico are from the personal collection of Vincent Perrichot (VP coll.), and their chemical fingerprints have not yet been published. In bold: the Mexican amber piece containing the rhopalosomatid wasp studied here.

\begin{tabular}{|c|c|c|c|c|}
\hline & $\begin{array}{r}\text { Dominican Republic } \\
\text { (VP coll.) }\end{array}$ & $\begin{array}{r}\text { Oise, France } \\
\text { (Nohra et al., 2015) }\end{array}$ & $\begin{array}{r}\text { Mexico } \\
\text { (VP coll.) }\end{array}$ & $\begin{array}{r}\text { Mexico } \\
\text { (this study) }\end{array}$ \\
\hline Bicyclic acids ${ }^{\mathrm{a}}$ & 15 & 59 & 4 & 6 \\
\hline Bicyclic alcohols ${ }^{b}$ & 17 & 14 & 2 & 17 \\
\hline Bicyclic hydrocarbons & 47 & 7 & 53 & 50 \\
\hline 1-Methylbicyclic hydrocarbons & 22 & 19 & 41 & 28 \\
\hline
\end{tabular}

Currently, the genus is represented in the Caribbean only by Rhopalosoma poeyi Cresson, 1865, and $R$. haitiense Townes, 1977 (Townes, 1977). However, neither of these species has a similar hind wing Rs*.

\section{Material}

Holotype: female, MB.I 5915, in Miocene amber from the Dominican Republic; the specimen is deposited in the amber collection of the Museum für Naturkunde Berlin. The specimen is almost completely preserved without any significant distortions. However, large parts of the legs are missing. The following syninclusions have been observed: one Collembola and one Mymaridae.

Paratype: male, MB.I 6046, in Miocene amber from the La Bucara mine in the Dominican Republic; the specimen is deposited in the amber collection of the Museum für Naturkunde Berlin. The specimen is completely preserved without any significant distortions. In order to access crucial characters of the fossil the amber piece has been cut into two fragments. The following syninclusions have been observed: two Hymenoptera (Mymaridae), four Diptera, one Isoptera, one large Isoptera wing, one unidentified Insecta, and one Araneae.

\section{Description}

Female (Fig. 4). Measurements. Total body length (head, without antenna, plus mesosoma plus metasoma) in lateral view $12.0 \mathrm{~mm}$. Maximum head width in dorsal view $2.0 \mathrm{~mm}$. Flagellar length (measured on left antenna with the last segment added from the right antenna) $11.4 \mathrm{~mm}$ (including pedicel and scapus $12.1 \mathrm{~mm}$ ). Mesosomal length in lateral view $3.2 \mathrm{~mm}$. Fore wing length $8.9 \mathrm{~mm}$. Hind wing length $6.5 \mathrm{~mm}$. Metasomal length in lateral view $7.8 \mathrm{~mm}$.

Head. (Base of right flagellum and last flagellomere of left flagellum not preserved.) FI-FV each with a pair of apical bristles. FI shorter than FII, which is about as long as flagellomeres III-V. FVI-FX becoming sequentially shorter from base to apex. Inner margin of compound eye emarginate. Depth of eye notch about the same size as the width of toru- lus. FI $5.0 \times$, FII $8.2 \times$, and FVII $9.5 \times$ as long as wide. TL $0.6 \times$, OOD $0.25 \times$, and MOD $1.0 \times$ LOD.

Mesosoma. Scutellum about half as long as mesoscutum and approximately 3 times as long as metanotum. Mesosternal lobes present, separated from mesosternum by slight constriction.

Fore wing. With eight enclosed cells: C, R, 1Cu, 1R1, 2R1, $1 \mathrm{Rs}, 1 \mathrm{M}$, and $2 \mathrm{Cu}$. Costal cell very narrow, apically slightly wider, over complete distance narrower than bordering veins. Cell 1 Rs about $1.05 \times$ as long as cell $1 \mathrm{R} 1$. Vein 1cu-a slightly bowed, distad of $\mathrm{M}^{1}$ by about $1.0 \times$ its length. Distance between $1 \mathrm{cu}-\mathrm{a}$ and $\mathrm{M}^{1}$ about half the distance between $1 \mathrm{cu}-\mathrm{a}$ and $\mathrm{m}$-cu. Vein $\mathrm{Rs}^{1}$ straight, about $0.8 \times$ length of $\mathrm{M}^{2}$. Pigmented traces of $2 \mathrm{~m}$-cu present. Anal cell without longitudinal spurious vein at its center (present in some Recent Asian Paniscomima). Pterostigma narrow.

Hind wing. $\mathrm{Rs}^{*}$ straight, recurrent, its anterior section meeting $\mathrm{Sc}+\mathrm{R}$ at an angle of about $55^{\circ}$. M diverging far beyond cu-a. With two clusters of hamuli. Basal hamuli straight. With 13 distal hamuli, all of same size and curvedand/or hook-like.

Legs. (The following parts of the legs are not preserved: tarsomeres III and following of right fore leg, tarsomere II and pretarsus of left fore leg, distal two-thirds of tarsomere I and tarsomere II of right mid leg, tarsomeres II-IV of left mid leg, distal half of tarsomere I and following of both hind legs.) Fore leg with one tibial spur. Mid leg and hind leg each with two tibial spurs, inner spur of hind tibia at base with dorsal tuft of bristles (calcar). Tarsomeres II-IV with apicolateral fenestrae. Pretarsal claws toothed medially (Fig. 4c). Arolia large.

Metasoma. Segment I about as long as mesosoma. Sting upcurved (Fig. 4a).

Pilosity. Body and wing membranes covered with regular distributed fine, short setae.

Male (Fig. 5). Measurements. Total body length (head, without antenna, plus mesosoma plus metasoma) about $7.3 \mathrm{~mm}$. Maximum head width in oblique ventral view about $1.0 \mathrm{~mm}$. Flagellar length (measured on left antenna in ventral view) $5.7 \mathrm{~mm}$ (including pedicel and scapus: $6.2 \mathrm{~mm}$ ). 

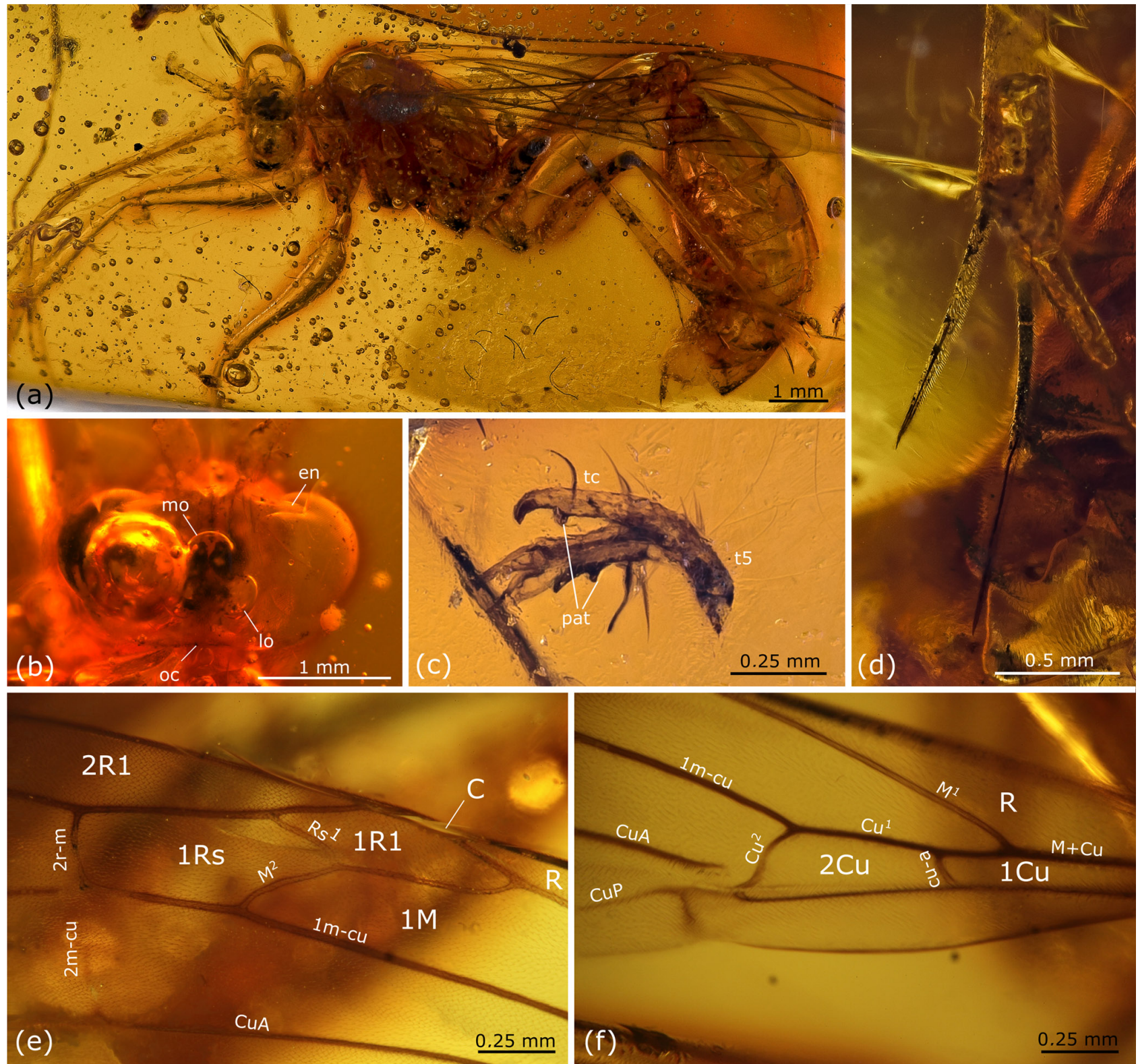

Figure 4. Rhopalosoma hispaniola sp. nov.: female, holotype, MB.I 5915, Miocene Dominican amber. (a) Overview. (b) Detail of the head in dorsal view. (c) Detail of the tarsal claws. (d) Distal section of mid tibia with tibial spurs. (e-f) Details of the right fore wing. Abbreviations used in (b) and (c): en - eye notch, lo - lateral ocellus, mo - median ocellus, oc - occipital carina, tc - tarsal claw, t5 - tarsomere 5, and pat - preapical tooth.

Mesosomal length in lateral view is about $2.3 \mathrm{~mm}$. Fore wing length about $5.6 \mathrm{~mm}$. Hind wing length about $3.8 \mathrm{~mm}$. Metasomal length about $4.3 \mathrm{~mm}$.

Head, mesosoma, and metasoma as in female except the following. Fore wing cell 1 Rs about $0.85 \times$ as long as cell 1R1. Vein Rs1 about $1.25 \times$ length of $\mathrm{M}^{2}$. Distance between 1cu-a and $\mathrm{M}^{1}$ about the same length as the distance between $1 \mathrm{cu}-\mathrm{a}$ and $\mathrm{m}-\mathrm{cu}$. Hind wing $\mathrm{Rs}^{*}$ meeting $\mathrm{Sc}+\mathrm{R}$ at an angle of about $50^{\circ}$. With eight distal hamuli. Plantar lobe present on tarsomeres I-IV. Pretarsal claws bifid. Metasomal segment I only two-thirds the length of mesosoma. Cuspis with $\sim 12$ peg-like bristles on apical section and $\sim 6$ apical setae. Digitus with $\sim 33$ peg-like bristles on apical section. Paramere spine-like, upcurved. Cercus paddle shaped and with apical setae.

\section{Note}

The intraspecific variation between the non-sex-specific characters (e.g., ratio of the length of fore wing veins $\mathrm{Rs}^{1}$ and 

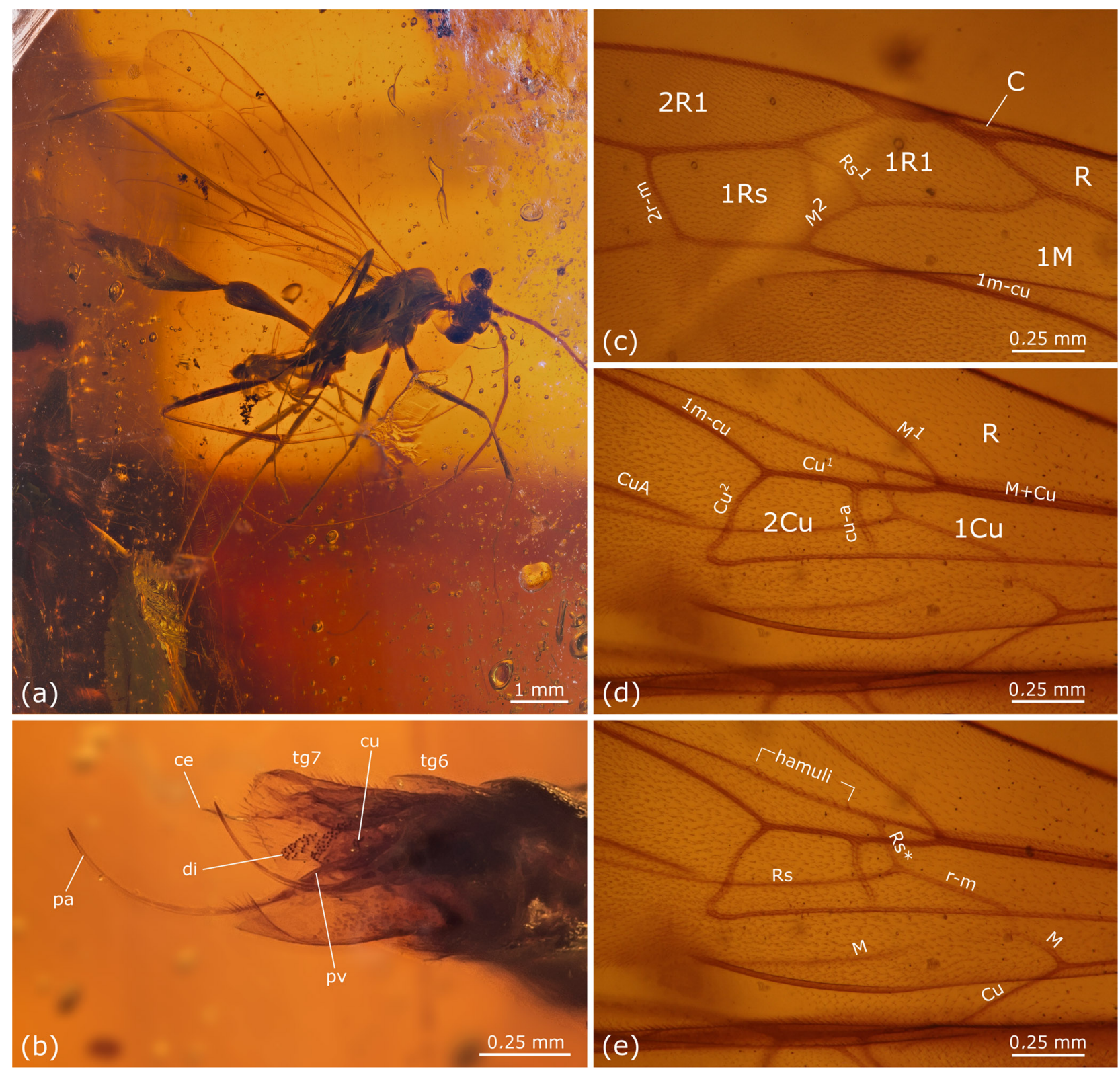

Figure 5. Rhopalosoma hispaniola sp. nov.: male, paratype, MB.I 6046, Miocene Dominican amber. (a) Overview. (b) Posterior metasoma with genitalia. (c) Details of right fore wing. (d-e) Details of right fore and hind wing with labeling of fore wing cells and venation (d) and labeling of hind wing venation (e). Abbreviations used in (b): ce - cercus, cu - cuspis, di - digitus, pa - paramere, pv - penis valve, tg6 tergite 6 , and $\operatorname{tg} 7$ - tergite 7 .

$\mathrm{M}^{2}$, ratio of the length of fore wing cells 1Rs and 1R1) seems to be slightly higher than in the Recent species of Rhopalosoma. However, we chose a conservative approach by assigning both specimens to the same species rather than describing two species based on only a single specimen of each sex.

\section{Etymology}

The specific epithet refers to the island of Hispaniola in the Caribbean where the fossils were found. It is a noun in apposition. 



Figure 6. Rhopalosoma sp.: female, MB.I 6549, Miocene Mexican amber. (a) Overview. (b) Left hind tarsus. (c) Pretarsus with claws. (de) Details of left fore wing. (f) Details of right hind wing. Abbreviations used in (b) and (c): pat - preapical tooth, tc - tarsal claw, tf - tarsal fenestrae, $\mathrm{t} 1$ - tarsomere $1, \mathrm{t} 2$ - tarsomere $2, \mathrm{t} 3$ - tarsomere $3, \mathrm{t} 4$ - tarsomere 4 , and $\mathrm{t} 5$ - tarsomere 5 .

\section{Rhopalosoma sp.}

(Fig. 6)

\section{Material}

Female, MB.I 6549, in Miocene amber from Chiapas, Mexico; the specimen is deposited in the amber collection of the Museum für Naturkunde Berlin. The specimen is almost completely preserved, except for part of the antennae, but it is largely distorted, except for the wings and legs. In order to access the crucial characters of the fossil the amber piece has been cut into three fragments. The following syninclusions have been observed: one Hymenoptera (Braconidae), six Diptera, one Heteroptera, and one Thysanoptera.

\section{Description}

Head, mesosoma, and metasoma as in $R$. hispaniola except the following. 
Measurements. Due to the heavy distortion of the specimen all measurements except for those of the wings, should be treated rather as an estimate of the general size. Body length (head, without antenna, plus mesosoma plus metasoma) in dorsal view $10.4 \mathrm{~mm}$. Head width in dorsal view $1.4 \mathrm{~mm}$. Mesosomal length in lateral view $2.9 \mathrm{~mm}$. Fore wing length $8.2 \mathrm{~mm}$. Hind wing length $6.3 \mathrm{~mm}$.

Fore wing. $1 \mathrm{Rs}$ cell about $0.85 \times$ as long as cell $1 \mathrm{R} 1$. $1 \mathrm{cu}-$ a slightly curved, distad of $\mathrm{M}^{1}$ by about $1.0 \times$ the length of 1 cu-a. Distance between $1 \mathrm{cu}-\mathrm{a}$ and $\mathrm{M}^{1}$ about $0.7 \times$ the distance between 1cu-a and m-cu.

Hind wing. Rs* very slightly curved (almost straight), its anterior section recurrent, meeting $\mathrm{Sc}+\mathrm{R}$ at an angle of $\sim$ $45^{\circ}$, posterior section almost vertical. With 11 distal hamuli (Fig. 6f).

\section{Note}

This specimen resembles the female from Dominican amber. Unfortunately, many important characters, such as the size and position of the ocelli, form of the inner eye margin, etc., cannot be examined due to the insufficient preservation of the fossil. However, we do not include this specimen in the type series of $R$. hispaniola to emphasize its different geological origin and the slightly different wing venation as an indication of a separate distinct species which might be properly described and named after new material becomes available.

Currently, the genus is represented in Mexico only by Rhopalosoma simile Brues, 1943, and R. obliquum Townes, 1977 (Townes, 1977). However, neither of these species has a similar hind wing $\mathrm{Rs}^{*}$.

\section{Discussion}

Based on the presence of a median tooth on the tarsal claws, females of Rhopalosoma are easily identified, and there is no doubt about the generic placement of the new species described herein. Townes (1977) divided Rhopalosoma into three species groups - the isopus, poeyi, and lanceolatum groups (comprising two, 14, and one species, respectively). Whereas the identification of Rhopalosoma at the species level remains a challenge, the new species likely belongs to the poeyi group based on the characters provided by Townes: front spur of mid tibia and hind tibia without narrow basal neck (as present in the lanceolatum group), and the form of tarsomere $\mathrm{V}$, which is gradually tapered at its apical 0.65 (parallel-sided in the isopus group). Nevertheless, the new species has some affinities with a member of the isopus group, and with $R$. minus in particular, by having the hind wing $\mathrm{Rs}^{*}$ straight and recurrent. But because this state is also found in Eorhopalosoma gorgyra, all Liosphex, and several Paniscomima (Lohrmann and Ohl, 2010; Lohrmann, 2011; Volker Lohrmann, personal observation, 2014), it can be assumed that this is the plesiomorphic character state compared to the angular or strongly bowed form found in many Recent species of Rhopalosoma. Townes (1977) regarded the isopus group as the "primitive species group". His assumption is based on the similarities of the morphology of the fifth tarsomeres with those found in Paniscomima, a genus he regarded as "definitely more primitive". Thus, the fossils likely do not represent the most archaic forms in the genus but represent either basal members of the poeyi group or an intermediate link between the isopus and the poeyi species group.

\section{Note}

The current contribution includes revised parts of a chapter used earlier in the $\mathrm{PhD}$ thesis of Volker Lohrmann, i.e., the description and discussion of the female of $R$. hispaniola (including Figs. 1d and 4b). Because the thesis includes a statement disclaiming all relevant nomenclatural acts from taxonomic use, the new taxon is formally described here to make its name available according to the ICZN (1999).

Data availability. No data sets were used in this article. 


\section{Appendix A}

Table A1. List of identified compounds and their retention times in Mexican amber. Target compounds were identified based on $m / z$ int and $m / z$ identification. Areas were integrated using the $m / z$ int, and the area on the total ion chromatogram was estimated using the mass spectra factor (MSF).

\begin{tabular}{|c|c|c|c|c|c|}
\hline & Retention time (min) & $m / z$ int & $m / z$ identification & MSF & $\operatorname{Area}(m / z$ int $)$ \\
\hline \multicolumn{6}{|l|}{ Bicyclic methyl esters } \\
\hline XIa & 42.781 & 236 & 161177 & 57 & 11992 \\
\hline XIIa & 43.581 & 236 & 176121161 & 121 & 5630 \\
\hline XIIIa & 47.362 & 250 & 175191235 & 67 & 56279 \\
\hline XIVa & 47.899 & 248 & 173133188 & 58 & 70849 \\
\hline \multicolumn{6}{|l|}{ Bicyclic alcohols } \\
\hline $\mathrm{XIb}$ & & 208 & 95177 & 158 & nd \\
\hline XIIb & & 208 & 55109177 & 95 & nd \\
\hline XIIIb & 47.704 & 222 & 95191207 & 62 & 187935 \\
\hline $\mathrm{XIVb}$ & 48.385 & 220 & 91132187 & 49 & 188631 \\
\hline \multicolumn{6}{|l|}{ Bicyclic methyl ethers } \\
\hline XId & & 222 & 95107177 & 152 & nd \\
\hline XIId & & 222 & 105119190 & 130 & nd \\
\hline XIIId & 44.435 & 236 & 109121189 & 79 & 33935 \\
\hline XIVd & 45.109 & 234 & 132187 & 62 & 65870 \\
\hline \multicolumn{6}{|c|}{ 1-Dimethylbicyclic hydrocarbons } \\
\hline XIc & 33.605 & 192 & 8195107177 & 23 & 186559 \\
\hline XIIc & & 192 & 95121177 & 16 & nd \\
\hline XIIIc & 38.780 & 206 & 95121191 & 19 & 693963 \\
\hline XIVc & 39.257 & 204 & 105119161 & 15 & 1452344 \\
\hline \multicolumn{6}{|c|}{ 1-Methylbicyclic hydrocarbons } \\
\hline A & 31.006 & 163 & 81107178 & 9 & 60884 \\
\hline B & 31.053 & 163 & 95178 & 17 & 50732 \\
\hline $\mathrm{C}$ & 32.209 & 163 & 81107178 & 14 & 40681 \\
\hline $\mathrm{D}$ & 32.511 & 163 & 95178 & 13 & 19600 \\
\hline $\mathrm{E}$ & 36.240 & 177 & 95121192 & 9 & 131382 \\
\hline G & 37.492 & 177 & 95121192 & 11 & 194635 \\
\hline $\mathrm{F}$ & 36.449 & 175 & 108190 & 12 & 448787 \\
\hline $\mathrm{K}$ & 36.641 & 175 & 119133190 & 25 & 645555 \\
\hline $\mathrm{H}$ & 37.284 & 175 & 93190 & 13 & 1549998 \\
\hline \multicolumn{6}{|l|}{ Aromatic hydrocarbons } \\
\hline Dimethyltetralin & 32.398 & 145 & 145160 & 5 & 107826 \\
\hline Trimethyltetralin & 38.077 & 159 & 159174 & 4 & 755296 \\
\hline Trimethylindene & 34.526 & 158 & 143158 & 12 & 100696 \\
\hline Dimethylnaphthalene & 36.120 & 156 & 141156 & 8 & 272332 \\
\hline Trimethylnaphthalene & 41.652 & 155 & 155170 & 7 & 3210319 \\
\hline Dimethylphenanthrene & 54.904 & 206 & 191206 & 4 & 203288 \\
\hline
\end{tabular}

nd - not detected 


\section{Appendix B}

\section{1-Methylbicyclic hydrocarbons}<smiles>CC1=C[C@]2(C)CCCC(C)C2CC1</smiles>

A<smiles>C=C1C(C)=CCC2C(C)CCCC12</smiles>

1-Dimethylbicyclic hydrocarbons<smiles>CC1=C[C@]2(C)CCCC[C@]2(C)CC1</smiles>

XIc<smiles>CC1=C[C@]2(C)CCC[C@H](C)[C@H]2CC1</smiles>

B<smiles>CC1=C(C)[C@H]2CCCC[C@H]2CC1</smiles>

G<smiles>CC1=CCC2C(C)CCC[C@]2(C)C1</smiles>

C<smiles>C=C1C(C)=CCC2CCCCC12</smiles>

H<smiles>CC1=C(C)[C@@H]2CCCC(C)(C)C2CC1</smiles>

XIIIC<smiles>CC1=CCC2C(C)CCC[C@]2(C)C1</smiles>

D

\section{Unknown structure}

K<smiles>C=C1C(C)=CCC2C1CCCC2(C)C</smiles>

XIVc

Bicyclic acids (analyzed as their methyl esters)<smiles>CC(=O)OC1CCC(C)=C[C@@H]1CCCC(C)(C)C</smiles>

XIa<smiles>CC(=O)[C@]1(C)CCC[C@@H]2CC(C)=CCC21</smiles>

XIla<smiles>CC(=O)C1(C)CCCC2C(C)=C(C)CCC21</smiles>

XIIIa<smiles>CC1=C(C)[C@@H]2CCCC(C)C2CC1</smiles>

E

Bicyclic alcohols (analyzed free or as their methyl ethers)<smiles>CC(=O)C[C@]1(C)CCC[C@]2(C)C=C(C)CCC21</smiles>

XIb,d<smiles>CCOCC[C@]1(C)CCC[C@@H]2CC(C)=CCC21</smiles>

XIIb,d<smiles>COC[C@]1(C)CCCC2C(C)=C(C)CC[C@H]21</smiles>

XIIIb,d<smiles>C=C1C(C)=CCC2[C@@H]1CCC[C@]2(C)C(C)=O</smiles>

XIVa

Figure B1. Molecules identified in the pyrolysates of Mexican amber. Individual compounds are labeled according to the identification of peaks in Fig. 2 and Appendix A. 
Author contributions. VL designed the study. VP carried out the preparation of the fossil amber samples for the THM-GC-MS analysis and for microscopic studies of the fossils. LJ did the chemical analysis. VL prepared the species descriptions. VL, VP, and PM prepared the photographs of the fossils. VL, VP, LJ, MO, and JPP wrote the paper. All authors contributed to the discussion and proofreading of the manuscript.

Competing interests. The authors declare that they have no conflict of interest.

Acknowledgements. We are sincerely thankful to Judy Gallagher (Woodbridge, Virginia) and Robert Lord Zimlich (Mobile, Alabama) for their kind permission to use their photographs, Jeremy Blaschke and his team (Jackson, Tennessee) for sharing their knowledge of the new host record of Rhopalosoma, Keith Luzzi (New Jersey) for making the two Dominican amber fossils available, and Christian Neumann (Museum für Naturkunde, Berlin) for allowing the study of all three inclusions. Partial support in the initial and the final stage of this project was provided by the "Studienstiftung des Deutschen Volkes" (to Volker Lohrmann) and the OSUR grant from program AO2 2018 for visiting researchers (to Vincent Perrichot, enabling Volker Lohrmann's work at the University of Rennes 1) respectively. Finally, we thank Denis J. Brothers and Mónica Solórzano Kraemer for their valuable comments on the manuscript.

Edited by: Torsten Scheyer

Reviewed by: Denis J. Brothers and Mónica Solórzano Kraemer

\section{References}

Anderson, K. B.: The nature and fate of natural resins in the geosphere - IV. Middle and Upper Cretaceous amber from the Taimyr Peninsula, Siberia - evidence for a new form of polylabdanoid of resinite and revision of the classification of Class I resinites, Org. Geochem., 21, 209-212, 1994.

Anderson, K. B.: New evidence concerning the structure, composition, and maturation of class Ib (Polylabdanoid) resinites, in: Amber, resinite, and fossil resins, edited by: Anderson, K. B. and Crelling, J. C., American Chemical Society Symposium Series, 617, 105-129, 1995.

Anderson, K. B., Winans, R. E., and Botto, R. E.: The nature and fate of natural resins in the geosphere - II. Identification, classification and nomenclature of resinites, Org. Geochem., 18, 829841, 1992.

Archibald, S. B., Rasnitsyn, A. P., Brothers, D. J., and Mathewes, R. W.: Modernisation of the Hymenoptera: ants, bees, wasps, and sawflies of the early Eocene Okanagan Highlands of western North America, Can. Entomol., 150, 205-257, 2018.

Ashmead, W. H.: Rhopalosomidae [sic!], a new family of fossorial wasps, P. Entomol. Soc. Wash., 3, 303-310, 1896.

Bray, P. S. and Anderson, K. B.: Identification of Carboniferous (320 Million Years Old) class Ic amber, Science, 326, 132-134, 2009.
Brues, C. T.: The American species of Rhopalosoma, Ann. Entomol. Soc. Am., 36, 310-318, 1943.

Cameron, P.: Fam. Braconidae, Olixon, in: Biologia CentraliAmericana, Insecta, Hymenoptera (Families Tenthredinidae Chrysididae), Vol. 1, by: Cameron, P., 412-413 + plate 16, 1887.

Cresson, E.: On the Hymenoptera of Cuba, Proc. Entomol. Soc. Phila., 4, 1-200, 1865.

Darling, D. C. and Sharkey, M. J.: Order Hymenoptera, in: Insects from the Santana Formation, Lower Cretaceous, of Brazil, edited by: Grimaldi, D. A., B. Am. Mus. Nat. Hist., 195, 209-229, 1990.

Dlussky, G. M. and Rasnitsyn, A. P.: Two new aculeate hymenopterans (Vespida $=$ Hymenoptera) from the Middle Eocene of United States, Paleontol. Zh., 5, 72-75, 1999 (in Russian; English translation in: Paleontol. J., 33, 546-549, 1999).

Engel, M. S.: The wasp family Rhopalosomatidae in mid-Cretaceous amber from Myanmar (Hymenoptera: Vespoidea), J. Kansas Entomol. Soc., 81, 168-174, https://doi.org/10.2317/JKES-712.11.1, 2008.

Grimaldi, D. A.: The age of Dominican amber, in: Amber, resinites, and fossil resins, edited by: Anderson, K. B. and Crelling, J. C., Am. Chem. Soc. Symp. Washington D.C., 203-217, 1995.

Gurney, A. B.: Notes on the biology and immature stages of a cricket parasite of the genus Rhopalosoma, Proc. U.S. Nat. Mus., 103, 19-34, 1953.

Hood, J. D.: Notes on the life history of Rhopalosoma poeyi Cresson, P. Entomol. Soc. Wash., 15, 145-147, 1913 [Note: additional comments on the paper and rhopalosomatids by Rohwer appear on pp. 147-148.].

Huber, J. T. and Sharkey, M. J.: Chapter 3. Structure, in: Hymenoptera of the world: An identification guide to families, edited by: Goulet, H. and Huber, J. T., Agriculture Canada, Research branch, Publication 1894/E, 13-59, 1993.

ICZN (International Commission on Zoological Nomenclature): International code of zoological nomenclature, 4th Edn., The International Trust for Zoological Nomenclature, c/o Natural History Museum, London, i-xxix, +306 pp., 1999.

Iturralde-Vinent, M. A.: Geology of the amber-bearing deposits of the Greater Antilles, Carib. J. Sci., 37, 141-167, 2001.

Iturralde-Vinent, M. A. and MacPhee, R. D. E.: Age and paleogeographical origin of Dominican amber, Science, 273, 1850-1852, 1996.

Lambert, J. B., Frye, J. S., and Poinar Jr., G. O.: Amber from the Dominican Republic: Analysis by nuclear magnetic resonance spectroscopy, Archaeometry, 27, 43-51, 1985.

Lambert, J. B., Santiago-Blay, J. A., and Anderson, H. M.: Chemical signatures of fossilized resins and recent plant exudates, Angew. Chem. Int. Edit., 47, 9608-9616, 2008.

Landis, G. P. and Snee, L. W.: ${ }^{40} \mathrm{Ar} /{ }^{39} \mathrm{Ar}$ systematics and argon diffusion in amber: implications for ancient earth atmospheres, Palaeogeogr. Palaeocl., 97, 63-67, 1991.

Linnaeus, C.: Systema naturæ per regna tria naturæ, secundum classes, ordines, genera, species, cum characteribus, differentiis, synonymis, locis, Tomus I, Editio decima, reformata, Salvius, Holmiæ, 824 pp., 1758.

Lohrmann, V.: A revision of the Paniscomima of the African subregion with the description of two new species from Malawi and Tanzania (Hymenoptera: Rhopalosomatidae), Zoosyst. Evol., 87, 371-378, https://doi.org/10.1002/zoos.201100014, 2011. 
Lohrmann, V. and Engel, M. S.: The wasp larva's last supper: 100 million years of evolutionary stasis in the larval development of rhopalosomatid wasps (Hymenoptera: Rhopalosomatidae), Foss. Rec., 20, 239-244, https://doi.org/10.5194/fr-20-2392017, 2017.

Lohrmann, V. and Ohl, M.: World revision of the wasp genus Liosphex Townes, 1977 (Hymenoptera: Rhopalosomatidae), Zootaxa, 2384, 1-43, 2010.

Lohrmann, V., Fox, M., Solis, M., and Krogmann, L.: Systematic revision of the New World Olixon Cameron with descriptions of $O$. melinsula sp. n. and the hitherto unknown female of $O$. bicolor (Hymenoptera: Rhopalosomatidae), Deut. Entomol. Z., 59, 259275, 2012.

Lohrmann, V., Falin, Z. H., Bennett, D. J., and Engel, M. S.: Recent findings of Olixon banksii in the Nearctic with notes on its biology (Hymenoptera: Rhopalosomatidae), J. Kansas Entomol. Soc., 87, 258-260, https://doi.org/10.2317/JKES130820.1, 2014.

Mason, W. R. M.: Standard drawing conventions and definitions for venational and other features of wings of Hymenoptera, P. Entomol. Soc. Wash., 88, 1-7, 1986.

Mason, W. R. M.: Cubitus posterior in Hymenoptera, P. Entomol. Soc. Wash., 92, 93-97, 1990.

McGown, M. W.: Rhopalosomatidae of Mississippi, available at: http://www.biochemistry.msstate.edu/resources/rhopalo-ms. asp (last access: June 2018), 1998.

Nel, A., Azar, D., and Hervet, S.: A new rhopalosomatid wasps [sic!] in the Paleocene of France (Hymenoptera), Ann. Soc. Entomol. Fr., 46, 211-215, 2010.

Nohra, Y. A., Perrichot, V., Jeanneau, L., Le Pollès, L., and Azar D.: Chemical characterization and botanical origin of French ambers, J. Nat. Prod., 78, 1284-1293, 2015.

Osten, T.: Hymenoptera: bees, wasps and ants, in: The Crato fossil beds of Brazil, edited by: Martill, D. M., Bechly, G., and Loveridge, R. F., Cambridge University Press, 350-365, 2007.

Penney, D.: Dominican amber, in: Biodiversity of fossils in amber from the major world deposits, edited by: Penney, D., Siri Scientific Press, Manchester, 22-41, 2010.

Perkins, R. C. L.: Some remarkable Australian Hymenoptera, Proc. Hawaii. Entomol. Soc., 2, 27-35, 1908.
Rodriguez, J., Waichert, C., Von Dohlen, C. D., Poinar Jr., G. O., and Pitts, J. P.: Eocene and not Cretaceous origin of spider wasps (Pompilidae): fossil evidence from amber, Acta Palaeontol. Pol., 61, 89-96, 2016.

Saussure, H. de (Ed.): Genre Anaxipha, in: Mission scientifique au Méxique et dans l'Amérique centrale, Recherches Zoologiques, ptie. 6, sect. 1, Études sur les Insects Orthoptères, 370-373, 1874.

Schlee, D.: Das Bernstein-Kabinett, Stuttg. Beitr. Naturk., Ser. C, 28, 1-100, 1990.

Schulz, W. A.: Spolia Hymenopterologica, Junfermannsche Buchhandlung, Paderborn, 355 pp., 1906.

Serrano-Sánchez, M. L., Hegna, T. A., Schaaf, P., Centeno-García, E., Pérez, L., and Vega, F. J.: The aquatic and semiaquatic biota in Miocene amber from the Campo La Granja mine (Chiapas, Mexico): paleoenvironmental implications, J. S. Am. Earth Sci., 62, 243-256, 2015.

Solórzano Kraemer, M. M.: Systematic, palaeocology, and palaeobiogeography of the insect fauna from Mexican amber, Palaeontogr. Abt. A, 282, 1-133, 2007.

Solórzano Kraemer, M. M.: Mexican amber, in: Biodiversity of fossils in amber from the major world deposits, edited by: Penney, D., Siri Scientific Press, Manchester, 42-56, 2010.

Townes, H. K.: A revision of the Rhopalosomatidae (Hymenoptera), Contr. Am. Entomol. Inst., 15, 1-34, 1977.

Uhler, P. R.: Orthopterological contributions, Proc. Entomol. Soc. Phila., 2, 543-555, 1864.

van der Werf, I. D., Fico, D., De Benedetto, G. E., and Sabbatini, L.: The molecular composition of Sicilian amber, Microchem. J., 125, 85-96, 2016.

Westwood, J. O.: XVIII. Descriptions of new genera and species of exotic Hymenoptera, T. Roy. Ent. Soc. London, 16, 327-332, 1868.

Westwood, J. O.: Thesaurus Entomologicus Oxoniensis; or, Illustrations of new, rare, and interesting insects, for the most part contained in the collections presented to the University of Oxford by the Rev. F. W. Hope, Clarendon Press, Oxford, 205 pp., 1874. 